\title{
An Overview of Generative Grammar in Albanian
}

\author{
Gilberta Hadaj \\ Gidiola Hysaj
}

PhD Candidate, Department of Education, Faculty of Social Sciences, Albanian University Email: gilberta_hoxha@gmail.com

\section{Doi:10.5901/ajis.2015.v4n2s2p231}

\begin{abstract}
In general, the concept of grammar is seen as a coherent system of principles that determine the formation of the generative syntax of a language, the basic idea is that the sentence is generated as an abstract structural representation, which becomes further from the derivation based on structure, following the universal principles and specific parameters for each language. The universal knowledge and language-specific parameters enables design respective grammar of these languages from which can then be generalized to a universal grammar. This paper will analyze how our customized linguistics generalizes it more specifically in terms of terminologies, terms as ingredients, complement, adjunct, etc. The limbs of the second functional generativist treatment have changed not only the terminology, but the scope of their use in relation to the position where they are. Research topic: Syntax study on the current Albanian generalization, terms and concepts, their use in Albanian.
\end{abstract}

Keywords: terms, syntax Albanian, generative syntax.

\section{Introduction}

Linguistics is one of the most prominent disciplines among the interdisciplinary social sciences. From all the linguistic theories, generativism which is also known as generative grammar transformer, or simply generative grammar, is the one that has given the greatest contribution to the growth of the name of linguistics. Generative theory has been accepted all over the world. The survival of generativism can be explained by its capacity to successfully build a coherent linguistic theory, which has answered many theoretical issues remained unclear by the previous linguistic theories. Although structuralism, which preceded generativism, gave a great contribution to the description of languages with varied structures, it was unable to uncover the common principles in their organization in addition to their differences, a process which would have guided it toward the discovery of the universal phenomena in the language and the explanation of many questions about the peculiarities of the linguistic structures.

During the last two decades it has been obvious that our linguists and researchers are making serious attempts to use contemporary methods and techniques in the description of the Albanian language. This process is not easy at all, because in order to apply new methods it is necessary to know first the concepts that stay at their core. Therefore, the period after ' 90 represents for the open-minded linguists the period of acquaintance with developments in contemporary linguistics. These efforts have already yielded the first fruits, especially in the area of syntax, which in the Albanian language mainstream was left behind. Recently, many articles, textbooks, master and doctorate thesis where syntactic phenomena are treated in the light of generative grammar, which still remains the main theory in the world linguistics are published (Memushaj, 2003).

Generative grammar does not have as its own object of study the discourse, but the language of human beings as an opportunity to use it as a means of communication. Language is not seen as a social phenomenon, but as a psychological phenomenon. It is conceived as a system of universal categories common to all languages of the world. These categories are lexical (noun, adjective, verb, etc.), syntactic (nominal syntagma, verbal syntagma, adjectival syntagma, etc.), phonetic (vocalic, consonantal, nasal, etc). The generativists are not the first to talk about a universal grammar, but unlike their predecessors they made a serious effort to find common features in human languages i.e. linguistic universals. 


\section{Research Methodology}

This paper aims to highlight some features of generative syntax terminology compared to the traditional syntax terminology of the Albanian language. In addition, it aims to review the way these terms are considered in each of the two syntaxes. For example the term phrase which we have encountered in the traditional language is considered by generativism as a constituent or syntagma etc. What these syntaxes have in common and how they differ from each other will be discussed later in this paper. Many other terms used in generative syntax will also be subject of this study. To have a deep understanding of the topic of our discussion we used a wide range of literature in the forms of books and articles written by Albanian and foreign researchers. The new concepts that have lately entered the field of syntax made us raise the question: what is happening with the Albanian syntax?!

\section{Syntax terminology}

The Terminology Glossaries are composed of compound terminology units or composite terminology like terms for phrases in generative grammar which are the most commonly used means in the construction of scientific terms by linguists. When dealing with terminology we encounter the phenomenon of the introduction of a foreign terminology in the Albanian language, such as: actant, advectiv, adjuksionet, cirkostantë, konstituente-bërthamë, konstituentejobërthamë.(Koleci,2011).The greatest contribution in the process of cleaning and enriching the Albanian terminology in the field of linguistics was given by the translators of the works written by the founders of this new syntactic direction and the Albanian linguists such as Mita Joseph, Rahmi Memushaj who in their works have used the translated terminology instead of the borrowed terminology. Some examples of the cleaning process: drejtim nga koka (en. Head government); elemente ndihmëse (en. Auxiliary); eptimi (angl.Flection); kallëzuesia (en. predicate); lëvizje të fshehura (en. COVERT movement). Examples of the enriching process: përngjitje (en. agglutination); përemra shënues (en. Espletivet); periudha (angl.Complex sentence); pranueshmëria (angl.Acceptability); rimarrja (en. Anaphora).(Graffi,2008). The translated terms help the reader understand the content of the terms and remember them easier when the new theories of generative grammar are discussed given that this theory has been introduced very rapidly in the Albanian language. Specifically: roli tematik i jashtëm; rregullat e strukturës së frazës; struktura e kllapave të etiketuara; struktura e sintagmës emërore; rrangu kryesor i pjesëve të ligjëratës (the external thematic role; the phrase structure rules, the structure of labeled brackets; syntagmatic structure of names; the principal rank of the discourse parts). However, in the course of the time, the extended linguistic units can be shortened in the expression of the concepts until to the size of a simple phrase (for e.g. the rules of nominalization / nominalization), or until to a compound word (e.g., adjective: adverb (ndajfolje) + adjective (mbiemer).

\section{The phrase: syntagma or clause}

In the traditional syntactic analysis introduced in the grammar of our academy of sciences, the sentence is broken down into phrases that are defined as subordinate conjunctions of nominal words which constitute the main parts of the phrase, whereas in the syntactic analysis applied by the modern linguistics the sentence is broken down into constituents that might be phrases, sentence parts or constituents of sentence parts. So the phrase and syntagma do not match each other. Syntagma or clause, may consist of a phrase or two or more compound phrases, but can also be a sentence part. So the phrase can be one of the possibilities for the realization of the syntagma but not a specific syntactic unit. Syntagma is a unit that has an undetermined size; a syntagma can be not only a single word, but also a subordinate clause. Syntagma is basically the working unit in the generative grammar. It should not be confused with the phrase of the traditional syntax.

The phrase or syntagma should be seen as categories that include heterogeneous components and contain some mainly evaluated features which are obvious in the nominative phrases given as follows:

$>$ The semantic autonomy, which ensures it the ability to stay alone as response to a question: (Vajzat) më shihnin sikur të isha unë fajtori. (Girls) see me as if I were the culprit. Cilat më shihnin...? Who was looking at me ...? (Vajzat) (Girls)

$>$ Replacing the pronoun $i$ saj 'her' with a pronoun (Vajzat)=(Ato)më shihnin... (Girls) $=($ They) were looking at ... see more

$>$ The ability of relocation in various positions in the sentence: (Vajzat) më shihnin...,ose më shihnin (vajzat)..... (Girls) ... look at me, or see me (girls) ..... 
Thus, in terms of syntax the clause or syntagma would be an abstract categorization of one or more heterogeneous components when taking into account the semantic aspect. Syntagma is a new term that is inconsistent with the traditional and current terminology of the Albanian language.

Syntagma is not compatible with the phrase. With syntagma we mean one or more components which, separately or together, have a sufficient understanding of the sentence (each element of syntagma contributes to the fulfillment of its semantic meaning and therefore contribute to perceiving it as a whole). The hierarchy of syntactic conjunctions expresses the semantic objective approach to reality.

\section{Functions of the secondary parts of speech}

The secondary functional parts in the generative grammar have changed not only in regard to the terminology but also to the field of their use depending on the position where they occur in the sentence. So for, in an existing term we might find many meanings in relation to its position in the syntagma or the sentence. The existing term gains a new label and a polysemantic value. More specifically: - the determinants in generative grammar have the value of specifier i.e. the complement and the adjunct. In the generative grammar specifier is called a number of non-finite words that act as syntagma's head. For example, demonstrative and indefinite pronouns, the words expressing the adjectives' degree, indefinite articles.

The elements associated with syntagmas (SE, SF, SM, PS) are called by Chomsky as their specifiers, because they show the grammatical features of syntagma's head. More concretely, in nominal syntagma the specifier is a complement, in adjectival syntagmas it is a degree word, in verbal syntagma it is an auxiliary element or modal. Determinant plays the role of the complement when it is part of a nominal syntagma by determining the meaning of the syntagma's head. For example, Ata të gjithë janë burra të gojës e të pushkës. - 'They are all men words and guns.' - A SE except the head is composed of adjuncts which can be a single word, a syntagma or a sentence (determinantssubjunctive and conjunctive). For example, Ky autobus, ndeshje e fituar, besimi që i krijuan mjekët - this bus, won match, the trust that the doctors created'. By now the term "adjunct" is used only in connection with the nominal and adjectival phrases that are joined with the linking verbs in sentences like:

a. Maria është një vajzë e bukur -Mary is a pretty girl.

b. Maria është e bukur - Mary is pretty.

Complements (objects) are internal argumente chosen by the head of syntagma. Words, that belong to lexical categories (noun, verb, adjective), and act as head of syntagma can take complements.

- With predicative complements are marked all those words or groups of words (with the exception of the verb) that are mandatory constituent of predicates, as for e.g., object of a transitive verb. The predicative complement is syntactically necessary for the completion of the predicative structure (that is why it is called "complement"). The complement is especially used for adverbial phrases. The difference between an adjuct and a predicative complement is clear: the first is an optional constituent (non-kernal) of the sentence, whereas the later is a mandatory constituent (kernal). - Objects in generative grammar are called "argument", which is used to designate the nominal phrases that are related to the verb (subject and object), but instead of it the term 'adjunct"can be used. Complements (objects) are internal arguments that are chosen by the head of syntagma. Words that belonging to lexical categories (name, verb, adjective), and serve as head of syntagmas can take complements.

\section{Defining the secondary parts}

In generative grammar "the internal argument" or "complement" is also known as "object". They are of different types according to the thematic roles assigned to them by the verb. According to the number of the arguments that a verb takes are defined its valences.

They are grouped as follows:

a) Zerovalent verbs: bubullon, gjëmon; 'thunder'

b) Onevalent verbs: Agroni ecën; Babai u zgjua; 'Agroni walks; the father is awoken'

c) Bivalent verbs: Vajza vështron qiellin; Djali nuk u bindet prindërve; 'the girl stares at the sky, the boy does not obey to his parents'(Graffi,2008)

d) Triivalent verbs: are the verbs of the type them 'say' and jap 'give': Djali i tha (i dha ) diçka vajzës - 'The boy gives something to the girl.' 
This division does not correspond with the traditional division of impersonal, intransitive and transitive verbs.

- Adjuncts in generative grammar are called "cirkostante". Circumstances are parts that may or may not depend on the predicate and that play an unimportant role in the sentence. For this reason they are called peripherals (from TESNIERE 1959; and Graffi 1994: 53).

The circumstance's function is played in the generative grammar by the adjunct. The adjunct is a constituent of the X-bar theory, and can take different positions in syntagma and include all the peripheral parts of the sentence, such as circumstances and isolated complements. More precisely, adjuncts of time, limitation, purpose, quality, cause and place. However, adjuncts are still a matter of discussion in X-bar theory.

- The complement is the element that belongs to the constituent that modifies the head of zero projection syntagma.

- With modifier is meant the syntagmatic component that has a limiting functions in relation to the lexical head lexical and as such it relates to the name, which is needed to limit its meaning (Lieber 1992: 38). Modifiers, specifiers and complements in regard to the language of discussion can be placed before or after the head of syntagma. Their position is determined by the peculiarities of each language and the function they perform in its grammar.

- Determinants are an integral part of the nominal syntagma (SN). In the graphical representation they are represented by the symbol Det (abbreviation of "determiners"). Along with the name they form under the operation Merge the nominal syntagma Merge (SN). E.g., quell'uomo - 'that man'. In X-bar theory the position of secondary parts in relation to the head of syntagma is explained through universal scheme.

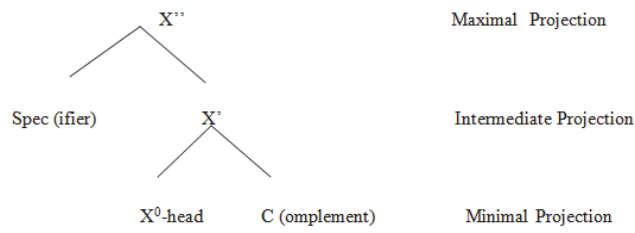

\section{Defining the simple sentence}

In the history of linguistics the simple sentence is known as: in Latin: a flawed form of speech, -phrasi $(\mathrm{m})$, in Greekphrasis, deriv. phrázein has the meaning " say '; in Albanian -Fjali-a,-te; in french. -proposition; in English.-clause sentence; in German. - Satz; in italian-proposizione. Similarly the phrase is known as- - fjali dykryegjymtyrëshe -in Albanian; in french -dirème; in german. - zweigliedriger. The designations of this term together with its types are found in: "Fjalorin krahasues të termave të gjuhësisë" (Belluscio G. \& Sh. Rokaj, 2011) in English, Italian, and French. Symbolically fjalia in Albanian generative grammar is represented as Fj. This shows that the symbols for this unit have not changed. Only its definitions are linguistically diverse in regard to the different linguistic perspectives applied. According to Albanian linguist who has studied generative grammar R. Memushaj "the sentence is the basic linguistic unit, which is understood as a judgment expressed orally or in writing form, that is composed of expression and content plans, that has a meaningful function and predicative intonation and has the predicator as its indispensible feature ". For J. Mitën "the sentence is the maximum projection of the verb flections, the argument of flection is SF, whereas as specifier of the flection is the subject." The sentence could be seen as a kind of syntagma that contains all the others. "The sentence is the maximum projection of verb's flection." It is generally accepted that the flection of the verb is the head of the sentence, which fall into the lexical head V (erb), A (djective, N(oun), P (ronoun) and in functional head.

\section{Conclusions}

Using descriptive, comparative and explanatory methods in this study we draw these conclusions:

1. The entering and adaptation of generative grammar's terminology in the Albanian language syntax, explains the great opportunity of Albanian as a language that can be studied in relation to other languages, with the purpose of finding the relative and absolute universals.

2. Changes in lexicology belong to the Albanian syntax terminology, which has expanded due to the processes of cleaning from the foreign terminology and enriching with Albanian terminology.

3. In grammar, the changes have had a slower pace because the secondary functional parts as considered from 
the generative grammar have changed their area of use in relation to the position where they occur. Specifically: determiners (specifier, complement and adjunct), objects (argument, complement), circumstance (circostante), determinants, modifiers.

4. From this perspective, innovation can be considered the naming of the secondary parts based on their position in the syntagmatic structure $X$. The acceptance of generative terms in Albanian is a great opportunity for the Albanian and foreign linguists to do comparative research on the terms necessary to describe different concepts and subsystems in the Albanian language.

5. The new definitions described by the Albanian linguists for the simple sentence, maximum projection of PRSH, its function and the appearance of rules for the phrase's structure in verbal sytagma was done as suggeted by the generative theory.

6. The innovation brought about by the generative terms in traditional Albanian language creates a new face of our language, a new generative and contemporary Albanian language. I wish that these results and innovations could be part of the academic communication of scholars and linguists in Albania and abroad.

\section{References}

Çeliku,M.; Domi,M.; Floqi,S.; Mansaku,S.; Përnaska,R.; Prifti,S.; Totoni,M. (2002), Gramatika e Gjuhës Shqipe,vëll.II, Akademia e Shkencave e Shqipërisë,Tiranë

Çeliku,M. (2013) Sintaksë e gjuhës shqipe,Botim I Universitetit te Elbasanit

Koleci,F.,Turano,G. (2011), Hyrje në sintaksn gjenerative të shqipes,SHBLU,Tiranë.

Graffi,G. (2008),Ç'është gramatika gjenerative (Përkthyer nga Prof.Dr.Rami Memushaj),Toena,Tiranë.

Graffi,G. (2008),Sintaksa (Përkthyer nga Dr.Blerta Topalli),Dituria,Tiranë.

Duro,A. (2009),Termi dhe fjala në gjuhën shqipe,Fan Noli,Tiranë.

Akademia e Shkencave e RPSH (1975), Fjalori I Termave të Gjuhësisë. Garzanti (), Dizionario Interattivo

Mita, J. (2005), Hyrje në sintaksën gjenerative, Shpresa, Prishtinë.

Lyons, J. (2001), Hyrie në gjuhësinë teorike (1968), përkth. E. Likaj, Dituria, Tiranë.

Domi, M. (1984), Dukuri të zhvillimit të structures sintaksore të gjuhës së sotme letrare shqipe: Studime filologjike, Tiranë, nr. 4.

Memushaj, R. (2003), Gjuhësia gjenerative,Tiranë.

Memushaj, R.(2006), Hyrje në gjuhësi, Toena, Tirana. 